and Northwestern, in which some Wisconsin legislators, in fear and trembling for the interests of the State, most "strongly, earnestly and emphatically protest" against the extension of the Northwestern's policy of consolidation in Wisconsin. Others have to do with land grants to these western roads.

The far-western group forms a most interesting part of the collection. One pamphlet defends the position of the majority of the Committee on Pacific Railroads in regard to a bill for granting aid to the Northern Pacific and Atlantic and Pacific Railroad Companies (the latter being a southern route, now part of the St. Louis and San Francisco), against an attack by the minority of that committee. Among other things, the majority argues that a nation cannot better invest its capital than in aiding its highways, that uninterrupted communication across the continent cannot be secured by one railroad to the Pacific, that the new roads will much more than pay for themselves, and that they will eventually lead to so close a welding of Canadian and Mexican with American interests that annexation will inevitably follow. Other representative items are the pamphlet containing speeches by the Hon. Otho R. Singleton and the Hon. E. D. Standiford in favor of granting government aid to the Texas Pacific Railroad, and that reprinting some of the testimony taken by the United States Pacific Railway Commission in the Congressional Investigation on the Management of the Pacific Railroads, which investigation was precipitated by the maturing of the government bonds of the Union Pacific in I899.

Since the above was written, Mr. Day has again come forward with a valuable contribution to the Society's material. This is described in the article - in this issue - on the Scientific American.

\title{
Early California
}

THE Library has just added to its material relating to the early history of California the second volume of "The State Register and Year Book of Facts" (I 859). It has much valuable statistical material relating to the political, social and economic aspects of the life of the state at that period; besides other interesting local data. Any material on early California is a welcome accession. 